\title{
Reduction of Escherichia Coli Using Metal Plates with the Influenced of Applied Low Current and Physical Barrier of Filter Layers
}

\author{
Michael Versoza ${ }^{1,2}$, Wonseok Jung ${ }^{1,3}$, Mona Loraine Barabad ${ }^{1,2}$, Sangwon Ko ${ }^{1}$, Minjeong Kim ${ }^{1}$ \\ and Duckshin Park ${ }^{1,2, *(1)}$ \\ 1 Transportation Environmental Research Team, Korea Railroad Research Institute, Uiwang City 16105, Korea; \\ mikeverz23@krri.re.kr (M.V.); worship611@skku.edu (W.J.); mlmbarabad@gmail.com (M.L.B.); \\ sko@krri.re.kr (S.K.); mjkim88@krri.re.kr (M.K.) \\ 2 Railway System Engineering, University of Science and Technology, Daejeon City 34113, Korea \\ 3 Mechanical Engineering Department, Sungkyunkwan University, Suwon City 16419, Korea \\ * Correspondence: dspark@krri.re.kr; Tel.: +82-31-460-5367; Fax: +82-31-460-5279
}

Received: 5 September 2019; Accepted: 10 October 2019; Published: 14 October 2019

\begin{abstract}
Although metal contact is known to reduce bacterial growth, the effects of physical barriers and electricity need further investigation. This study examined the bacteria-reducing properties of copper and stainless-steel metal plates with an added electrical current and up to three filter layers on the growth of Escherichia coli (bacteria) and MS2 bacteriophages (virus). When used with a stainless-steel plate, electricity increased bacteria reduction by $39.5 \pm 2.30 \%$ in comparison with no electricity added, whereas a three-layer physical barrier decreased its efficiency. Copper also reduced the growth of bacteria, by $58.2 \pm 8.23 \%$, and the addition of electricity reduced it further $(79.5 \pm 2.34 \%)$. Bacteriophages were also affected by the metal contact. Further experiments showed that MS2 was also reduced by copper, to $82.9 \pm 4.5 \%$ after $24 \mathrm{~h}$ at $37^{\circ} \mathrm{C}$.
\end{abstract}

Keywords: Contact-Killing; Metal-Plates; electricity; Filter-Layers; bacteria; virus

\section{Introduction}

Copper metal surfaces kill different species of bacteria efficiently (Grass et al., 2011). Prolonged contact leads to damage to cell membranes, which are overwhelmed by intracellular copper, reducing bacterial growth [1,2]. Contact killing is usually rapid, and no bacteria fully resistant to copper have been discovered [3].

The biocidal properties of copper metal surfaces provide an easy way to counter pathogen spread via human carriers. Egyptian writing from 2600-2200 BC indicated that copper was used to treat chest wounds and drinking water [4]. In developing countries, copper is used for water treatment because of its low cost [5]. Doorknobs and other touched surfaces are potential sources of nosocomial infection, and some studies have reported that materials made from brass and bronze prevent the spread of microbes in hospitals [6]. Marais et al. (2010) [7] observed an overall 71\% reduction in bacteria in a room where items were covered with copper sheets. Depner et al. (2016) [8] conducted a study in commercial poultry hatcheries and found that mesophilic microorganisms, fungi, and yeasts were absent when the samples were exposed to copper surfaces compared with stainless-steel. Stainless-steel is commonly used in healthcare facilities due to its corrosion resistance and dirt-free appearance, but it has no antibacterial properties [9].

One mechanism of copper toxicity is the change between its cuprous [Cu(I)] and cupric $[\mathrm{Cu}(\mathrm{II})]$ oxidation states. This involves a Fenton-type reaction that generates reactive hydroxyl radicals. 
The copper competes with other metal ions that play important roles in protein binding sites [10] and displaces iron from iron-sulfur clusters [11].

The application of a direct current has also been used to kill bacteria [12-14]. Electricity is thought to damage cell membranes through the irreversible loss of the semi-permeable barrier function [15]. A direct current killed Escherichia coli in liquid suspension, which depended on the strength of the current $[16,17]$, although the liquid medium might also have affected the efficiency of electricity in these studies. By contrast, Zituni et al. (2014) [18] found that a low direct current with gold electrodes on solid agar had low efficiency, although they demonstrated that increasing the electrical field increased the membrane potential, thereby hindering proton translocation. This reduced both the $\mathrm{pH}$ and adenosine triphosphate (ATP) synthesis outside the cell membrane. An electrical field might be inefficient if the medium itself cannot transfer it to the target bacteria. This might also be affected by the type of electrode used in the experiments [19]. Only a few studies have examined the influence of electricity on the growth of bacteria, and the authors wanted to explore the phenomenon further.

The present experiment used copper plates to examine the effects of electricity and solid medium (agar) on Escherichia coli and viruses, as copper is a good conductor and is known to kill bacteria. To examine the effects of metal conduction copper was compared with stainless-steel (SS). Further, whether a physical barrier (simple cloth filters) influenced the efficiency of killing bacteria with copper and electricity was also investigated to examine ways to improve the elimination of bacteria and viruses in water samples and other media.

\section{Material and Methods}

\subsection{Bacterial and Virus Preparations}

This experiment used F-specific RNA bacteriophages (E. coli MS2 bacteriophages; ATCC 15597-B1, Manassas, VA, USA) for plaque counting. MS2 stock solution was prepared in accordance with the product sheet from ATCC. The stock solution $(1000 \mu \mathrm{L})$ was frozen at $-75^{\circ} \mathrm{C}$, and some stock solution was incubated with the host to check its viability. Then, 1- $\mu \mathrm{L}$ aliquots of MS2 stock solution were added to $50 \mathrm{~mL}$ sterilized deionized water, and diluted by a factor of three. The incubated host was then added. Escherichia coli (C3000, ATCC 15597) was cultured in accordance with the product sheet from ATCC within $24 \mathrm{~h}$. A stock solution of E. coli was mixed with $40 \mathrm{~mL}$ of sterilized tryptic soy broth (TSB) and shaken at $150-200 \mathrm{rpm}$ at $37^{\circ} \mathrm{C}$ in an incubator for 6-12 h. Then, $0.3 \mathrm{~mL}$ of host solution, $0.1 \mathrm{~mL}$ of bacteriophages, and $24 \mathrm{~mL}$ of soft agar (30 $\mathrm{g}$ TSB and $7.7 \mathrm{~g}$ agar in $1 \mathrm{~L}$ distilled water) were mixed and poured into Petri dishes.

\subsection{Metal Plates, Filter and Applied Current}

The experiment used stainless-steel (SS304) and copper (Cu-99.9\%) plates (D\&S Tech, South Korea) designed to fit in a 150-mm-diameter Petri dish with four external anchors to attach the cables from a low-frequency device generator (OTS H-306; Hanil Meditech Probe, South Korea) operating at $10 \mathrm{~Hz}$ for $50 \mathrm{~min}$. In addition, $0-3$ layers of filter paper were placed above the copper plates. Then, $0.3 \mathrm{~mL}$ of the E. coli and $0.1 \mathrm{~mL}$ of MS2 bacteriophages were used to determine the number of plaque-forming units (PFU) of the cultured host. Finally, $29 \mathrm{~mL}$ of tryptic soy agar (TSA) was added to the Petri dish and incubated at $37^{\circ} \mathrm{C}$ for $12-18 \mathrm{~h}$.

\subsection{Efficiency Reduction Calculations}

Figure 1a outlines the experimental design. The Petri dishes with 30-300 PFUs were used to compare the metal-treated and untreated samples and quantify the effects. All plates were examined, and the number of colonies in PFUs/mL was calculated as follows:

$$
N_{\left(\frac{C F U}{m L}\right)}=\frac{P F U}{\alpha} \times \frac{1}{\mathrm{~d}_{\mathrm{i}}}
$$


where PFU is the total plaque count in the Petri dish, $\alpha$ is the volume of virus added (mL), and $d_{i}$ is the dilution factor of the virus. After counting the plaques in each plate, the concentrations were expressed in logarithmic form (base 10). The reduction efficiency (\%) was calculated as follows:

$$
(\%)_{\text {Reduction Efficiency }}=\left\{1-\left(\frac{N_{\text {Treated }}}{N_{\text {Control }}}\right)\right\} \times 100
$$

where $N_{\text {Treated }}$ is the metal-treated samples, and $N_{\text {control }}$ is the control. The $\log _{10}$ difference in $N$ was calculated as follows:

$$
\log \operatorname{Diff} f_{\left[\log _{10}(N)\right]}=\log _{10}\left(N_{\text {control }}\right)-\log _{10}\left(N_{\text {treated }}\right)
$$

where $\log$ Diff is the difference between the logarithmic values of the control plaques and the plaques with metal plates and filter layers. The differences between treatments with and without electricity were also calculated. All calculations were based on our previous study [20]. All experiments were repeated multiple times, and three to four experiments with consistent data were used to calculate the geometric means and standard deviations.

(a)

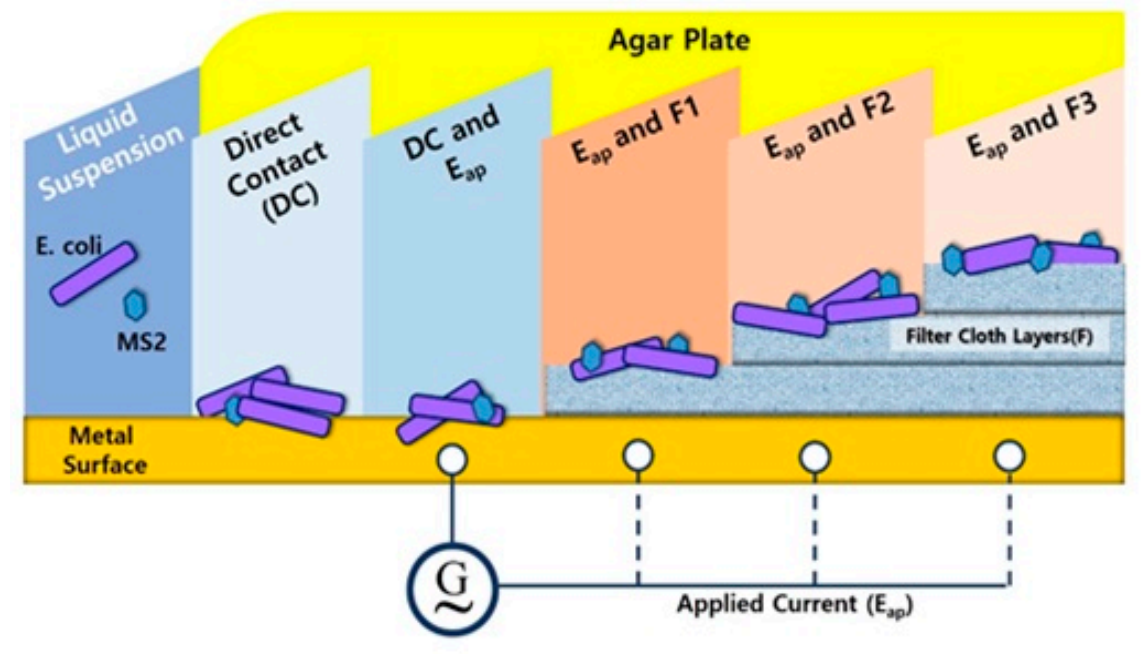

(b)
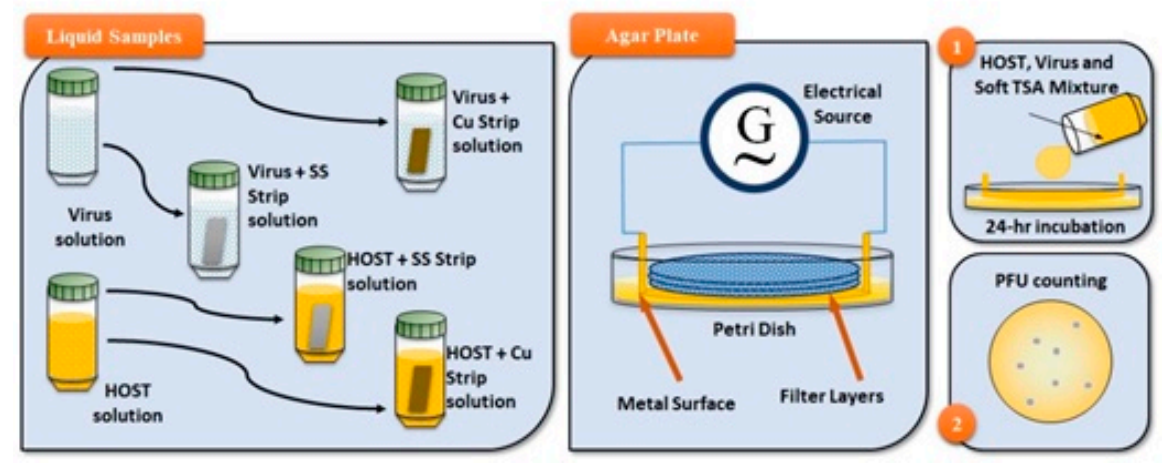

Figure 1. The conceptual framework of the study (a). All experiments with applied electricity were done on agar plate while the liquid samples were incubated first in liquid solutions before placing in agar plates. Liquid samples and Agar plates are also presented here in detail $(\mathbf{b})$. All samples were incubated in $24 \mathrm{~h}$ and PFU counting were done afterwards.

\subsection{Liquid Samples with Metal Strips}

This study also examined whether copper or stainless-steel metal strips influenced the growth of the model virus and its host (Figure $1 b$ ). In the experiments using agar plates, both the host and virus 
were present. The presence of metal might also affect the behavior of the virus. To address this, E. coli and MS2 were prepared separately under the same conditions as above $(30 \mathrm{~mL}$ total solution in $50 \mathrm{~mL}$ polypropylene tubes) with a rectangular metal strip $(-0.2 \mathrm{~g})$ and incubated at $37^{\circ} \mathrm{C}$ and $150-200 \mathrm{rpm}$. The MS2 was incubated without its host to determine the longevity of the virus in water samples with and without the metal strips. These were prepared by adding stock solution $(1 \mu \mathrm{L})$ to $50 \mathrm{~mL}$ of distilled water and separating the mixture into three parts (one each for the control and each metal). The E. coli was also prepared with stock solution and separated into three parts. After 7 and $24 \mathrm{~h}, 1 \mathrm{~mL}$ of liquid was withdrawn. For the metal-treated and control E. coli liquid samples, fresh virus stock solution ( $0.1 \mathrm{~mL}$ diluted to $50 \mathrm{~mL}$ with deionized water) was ready for mixing in a Petri dish and the same as for metal-treated and control MS2 liquid samples after incubating the host for $6-7 \mathrm{~h}$ at $37^{\circ} \mathrm{C}$ and 150-200 rpm. This experiment was done in triplicate.

\section{Results}

\subsection{PFU Difference with the Influence of Filter Layers and Electricity.}

The log differences between the control and treated samples were determined for all experimental conditions (Table 1). The log difference was higher in the presence of a $\mathrm{Cu}$ plate only ( $\mathrm{Cu}-0$, no filters) than with a SS plate only (SS-0, no filters) $\left(0.379 \pm 0.05\right.$ versus $\left.0.137 \pm 0.02 \log _{10} \mathrm{PFU} / \mathrm{mL}\right)$, indicating greater inactivation with copper. By contrast, with three filter layers, the log difference was higher with SS-0 than with Cu-0 $\left(0.361 \pm 0.02\right.$ vs. $\left.0.308 \pm 0.10 \log _{10} P F U / m L\right)$. This indicated that the E. coli was affected more by the presence of $\mathrm{Cu}$, but the bacterial growth was affected less as the filter layers increased.

When current was applied to the metal plates (SS-Eap and Cu-Eap), the log difference was higher compared with no voltage (SS-0 and Cu-0), increasing to $0.476 \pm 0.14$ and $0.688 \pm 0.01 \log _{10} \mathrm{PFU} / \mathrm{mL}$ for the SS and Cu plates, respectively, without added filters. With three filter layers, the log difference decreased from $0.572 \pm 0.02$ with zero filters with the $\mathrm{Cu}$ plate to $0.368 \pm 0.13$ and $0.242 \pm 0.17 \log _{10}$ $\mathrm{PFU} / \mathrm{mL}$ with one, and three filter layers, respectively; with the SS plate, it decreased from $0.353 \pm 0.14$ with zero to $0.348 \pm 0.02$ and $0.339 \pm 0.04 \log _{10} \mathrm{PFU} / \mathrm{mL}$ with one and three filter layers, respectively.

Table 1. The difference of colony forming units (at Log base 10) between the blank samples and the treated samples with metal plates and filter layers.

\begin{tabular}{ccccc}
\hline \multicolumn{5}{c}{ Log Difference } \\
\hline \multirow{4}{*}{ Treatment } & \multicolumn{4}{c}{ Filter } \\
\cline { 2 - 5 } & $\mathbf{\# 0}$ & $\mathbf{\# 1}$ & $\# \mathbf{2}$ & \#3 \\
\hline SS-0 & $0.137 \pm 0.02$ & $0.111 \pm 0.09$ & $0.219 \pm 0.03$ & $0.361 \pm 0.02$ \\
Cu-0 & $0.379 \pm 0.05$ & $0.354 \pm 0.05$ & $0.239 \pm 0.09$ & $0.308 \pm 0.10$ \\
SS-Eap & $0.476 \pm 0.14$ & $0.353 \pm 0.14$ & $0.348 \pm 0.02$ & $0.339 \pm 0.04$ \\
Cu-Eap & $0.688 \pm 0.01$ & $0.572 \pm 0.02$ & $0.368 \pm 0.13$ & $0.242 \pm 0.17$ \\
\hline
\end{tabular}

* Note: Stainless steel and copper with NO electricity added (SS-0, Cu-0) and with added electricity (SS-Eap, Cu-Eap).

\subsection{Influenced on Filter Layers}

The filter layers reduced the effects of the metal plates on the host bacteria. With SS-0, the inactivation was directly proportional to the increasing number of filter layers, at $27.1 \pm 6.00,22.6 \pm 6.21,39.6 \pm 3.50$, and $56.4 \pm 8.61 \%$ for 0 to 3 layers, respectively (Figure 2). By contrast, the inactivation with Cu-0 was indirectly proportional to the number of filter layers, at $58.2 \pm 8.23,52.2 \pm 5.42,42.4 \pm 4.53$, and $50.8 \pm 5.43 \%$, respectively.

With electricity, the inactivation efficiency of SS-Eap was $66.6 \pm 4.51,55.7 \pm 5.53,55.1 \pm 10.32$, and $54.2 \pm 3.2 \%$ as the number of filter layers increased, whereas the values for Cu-Eap were $79.5 \pm 2.34$, $71.0 \pm 8.92,57.1 \pm 2.36$, and $42.8 \pm 1.32 \%$, which surpassed the values for stainless-steel using a current 
with fewer filter layers. Both metal plates had roughly the same inactivation efficiency with three filter layers.

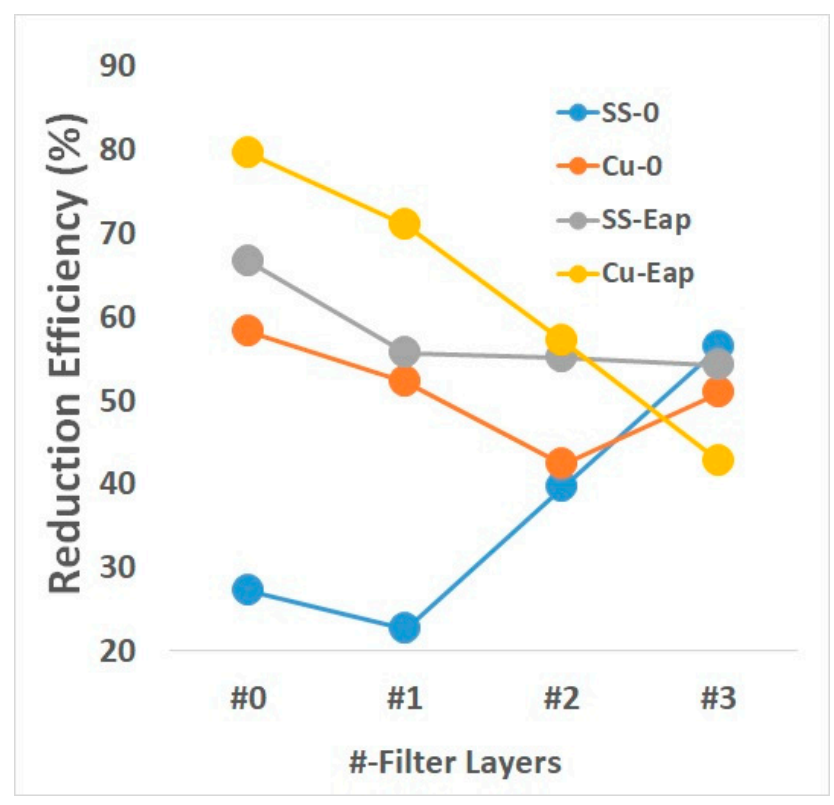

Figure 2. Inactivation efficiency of the non-applied and applied current experiments.

\subsection{Differences of Applied Current}

Figure 3 shows the percentage difference (Diff\%) between the stainless-steel (SS-0/SS-Eap) and copper (Cu-0/Cu-Eap) metal plates without (Cu-0/SS-0) and with (Cu-Eap/SS-Eap) current. Comparing both metals without a current, $\mathrm{Cu}-0 / \mathrm{SS}-0$ had a difference of $31.14 \pm 1.60 \%$. This decreased to $29.57 \pm 1.90 \%$ with one and $2.78 \pm 0.21 \%$ with two filter layers. With an applied current, the difference between metals was $12.92 \pm 5.20 \%$. The difference increased slightly to $15.32 \pm 3.10 \%$ with one filter layer and fell to $2.02 \pm 0.09 \%$ with two layers.

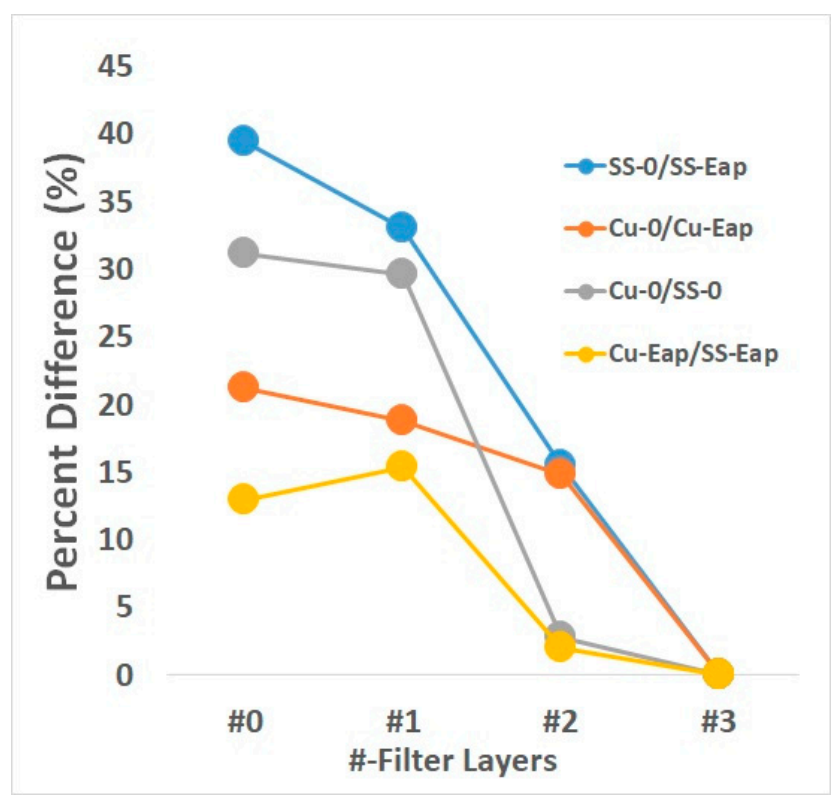

Figure 3. The percentage difference between the applied and non-applied current of metal plates with the influence of filter cloth layers. 
Comparing each metal with and without a current, SS-0/SS-Eap had a difference of $39.5 \pm 2.30 \%$, which decreased to $33.1 \pm 4.50 \%$ (one filter layer) and $15.5 \pm 1.70 \%$ (two filter layers). Cu-0/Cu-Eap had a difference of $21.3 \pm 3.20 \%$, which decreased to $18.8 \pm 2.80 \%$ (one filter layer) and $14.8 \pm 1.20 \%$ (two filter layers). The plates of both metals had roughly the same inactivation efficiency with three filter layers. The difference was scored as $0 \%$.

\subsection{Metal Strips in Liquid Samples}

To determine whether the metal strips influenced the behavior of MS2, the metal strips were added during the incubation of MS2 and E. coli separately. After incubating $1500 \mathrm{PFU} / \mathrm{mL}$ for $7 \mathrm{~h}$, the counts for the E. coli $(\mathrm{H})$ and MS2 (V) controls were 10,931 \pm 60.07 and $6941 \pm 52.3 \mathrm{PFU} / \mathrm{mL}$, respectively. With the metal strips, the values were lower, at $9581 \pm 28.9$ (H-SS) and $1586 \pm 62.0 \mathrm{PFU} / \mathrm{mL}$ (V-SS), respectively, for stainless-steel and $1536 \pm 17.45(\mathrm{H}-\mathrm{Cu})$ and $1188 \pm 30.2 \mathrm{PFU} / \mathrm{mL}(\mathrm{V}-\mathrm{Cu})$ for copper (Figure 4).

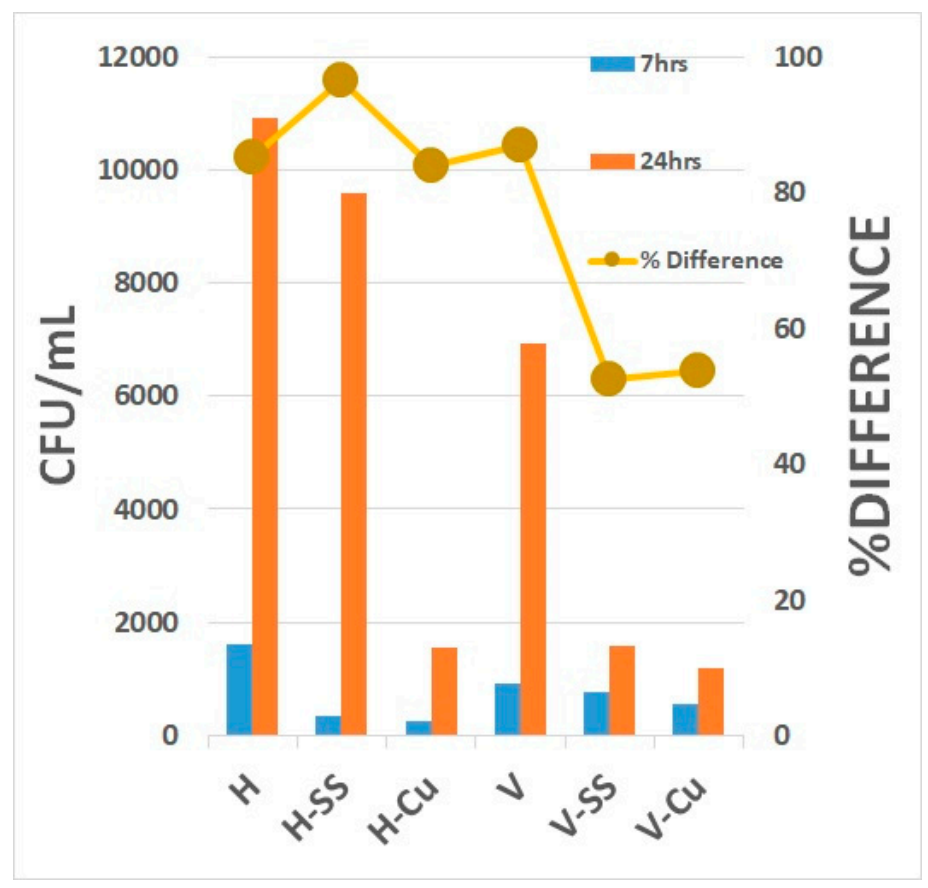

Figure 4. Colony-forming unit (PFU/mL) between incubation intervals of 7-hrs and 24hrs. Conditions are H: E. coli, H-SS: with stainless-steel, H-Cu: with copper; and V: MS2 Bacteriophages; V-SS: with stainless steel, and V-Cu: with copper.

After incubation for $24 \mathrm{~h}$, the host levels increased in all samples, with a percentage difference (between 7 and $24 \mathrm{~h}$ ) of $85.2 \pm 2.5,96.5 \pm 10.2$, and $83.9 \pm 15.2 \%$ for the control, stainless-steel strip, and copper strip, respectively (Table 2). The MS2 count difference increased to $87.0 \pm 3.2 \%$ for the control, but decreased with both the stainless-steel ( $52.5 \pm 5.1 \%)$ and copper ( $53.7 \pm 3.4 \%$ ) strips. After incubating the liquid samples for $24 \mathrm{~h}$, there was a significant increase in the reduction efficiency of both E. coli and MS2 bacteriophages, as shown by comparing the control and metal-treated samples. With the copper metal strips, the host and virus samples were reduced to $86.0 \pm 6.5 \%$ and $82.9 \pm 4.5 \%$, respectively, whereas with stainless-steel metal strips, the virus was reduced to $77.2 \pm 2.1 \%$ and the E. coli to $12.4 \pm 3.2 \%$ (Figure 5). 
Table 2. Colony-forming unit (PFU/mL) of different condition at different incubation time.

\begin{tabular}{cccc}
\hline \multirow{2}{*}{ Condition } & \multicolumn{2}{c}{ Incubation Time } & \multirow{2}{*}{ \% Difference } \\
\cline { 2 - 3 } & $\mathbf{7} \mathbf{h}$ & $\mathbf{2 4} \mathbf{~}$ & \\
\hline E. coli $($ Control) & $1621.9 \pm 2.3$ & $10935.1 \pm 32.4$ & $85.2 \pm 2.3$ \\
E. coli $+\mathrm{SS}$ & $336.9 \pm 10.2$ & $9580.9 \pm 25.1$ & $96.5 \pm 2.5$ \\
E. coli $+\mathrm{Cu}$ & $247.8 \pm 15.2$ & $1535.9 \pm 35.6$ & $83.9 \pm 2.6$ \\
MS2 $($ Control $)$ & $905.6 \pm 3.2$ & $6940.9 \pm 20.3$ & $87.0 \pm 3.2$ \\
MS2 + SS & $753.1 \pm 45.2$ & $1586.1 \pm 13.2$ & $52.5 \pm 5.1$ \\
MS2 + Cu & $550.3 \pm 55.2$ & $1188.0 \pm 65.2$ & $53.7 \pm 6.5$ \\
\hline
\end{tabular}

*\% Difference: The difference between $24-\mathrm{h}$ and $7-\mathrm{h}$ incubation time at percentile.

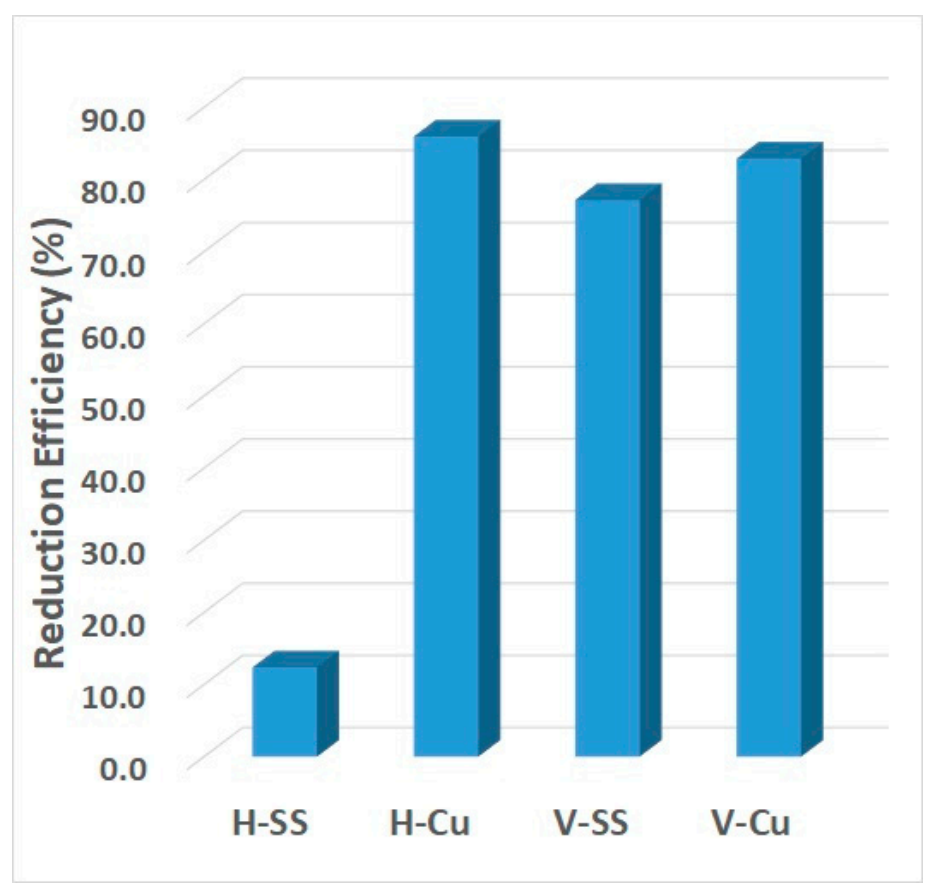

Figure 5. Reduction efficiency of liquid samples with metal strips. H-SS: with stainless steel, H-Cu: with copper; and V-SS: with stainless steel, and V-Cu: with copper.

\section{Discussion}

Copper is essential in biological systems, but higher concentrations can be toxic and lead to the generation of hydrogen radicals that can damage cellular [21-24]. The reaction of dihydrogen peroxide with superoxide occurs at a constant rate (Equation (1)), and is accelerated in the presence of copper or iron. $\mathrm{Cu}$ (II) is reduced by superoxide (Equation (2)) and re-oxidized by dihydrogen peroxide (Equation (3)), which results in the production of hydrogen radicals.

$$
\begin{gathered}
\mathrm{H}_{2} \mathrm{O}_{2}+\mathrm{O}_{2}^{-} \rightarrow \mathrm{O}_{2}+\mathrm{OH}^{-}+\mathrm{OH}^{\bullet} \\
\mathrm{Cu}(\mathrm{II})+\mathrm{O}_{2}^{-} \rightarrow \mathrm{Cu}(\mathrm{I})+\mathrm{O}_{2} \\
\mathrm{Cu}(\mathrm{I})+\mathrm{H}_{2} \mathrm{O}_{2} \rightarrow \mathrm{Cu}(\mathrm{II})+\mathrm{O}_{2}+\mathrm{OH}^{-}+\mathrm{OH}^{\bullet}
\end{gathered}
$$

Hydrogen radicals are highly reactive oxidants with a half-life of 1 nanosecond in aqueous solution, and they can damage biomolecules in cells [25]. Copper can denature E. coli DNA [2], as can superoxide from the generation of hydroxyl radicals [11,26].

Copper can reduce the growth of bacteria and viruses, as demonstrated in this study with E. coli and MS2 bacteriophages. Copper metal surfaces can potentially kill pathogens. It was found that a $24-h$ 
exposure to copper resulted in greater reductions. A greater reduction in the growth of E. coli was also observed when a voltage was applied to the copper, as shown in Figures 2 and 5. However, even with an applied current, no significant change occurred when three filter layers were used. Under this condition, stainless-steel and copper had roughly the same inactivation efficiency. SS-0 outperformed $\mathrm{Cu}-0$ when a current was applied, but not when filter layers were added.

In contact killing, there was a large difference as increasing filter layers were added. Without a current, stainless-steel (SS-0) had lower efficiency, demonstrating that stainless-steel is not ideal for inactivating E. coli. With increasing filter layers, the bacteria and viruses had no contact with the metal, resulting in less change in the phages in the Petri dishes. Similarly, the physical barrier of the three filter layers eliminated the effects of copper and electricity on growth. The inactivation efficiency was also reflected in the PFU differences because the physical barrier prevented contact between E. coli and the metal surface. Stainless-steel alone did not affect the growth of bacteria, and the physical barrier of filters also prevented the virus and its host from contacting the metal, lowering the inactivation efficiency.

The possibility that MS2 might also be affected by the metal plates was investigated by separating it from its host bacteria. Using liquid samples, the effects of 0.2-g metal strips on the virus after incubation for 7 or $24 \mathrm{~h}$ could be seen. The separate growth of the host bacteria and viruses was greater after 24 than after $7 \mathrm{~h}$. MS2 bacteriophages incubated at $37^{\circ} \mathrm{C}$ were still active after $24 \mathrm{~h}$. The increase in MS2 growth might have been influenced by the use of a fresh host (6-h incubation), as the growth of phages adapts to factors such as temperature, growth phase, $\mathrm{pH}$ [27], or the genomics of its host bacteria [28]. In our study, both conditions influenced its growth because the growth of the control was significantly higher than that of the samples with the metal strips. The virus was reduced by more than $50 \%$ (based on time intervals) with both metals. Other studies have shown that the growth of different viruses was reduced by copper or silver. Copper affected the growth of influenza A virus [29] after $6 \mathrm{~h}$, but not other bacteriophages [30]. Copper exhibited higher inactivation efficiency for MS2 bacteriophages in our study than in another study using different copper concentrations [31]. The mechanism by which copper affects in MS2 on a genomic scale remains to be determined.

The host bacteria were reduced less in the liquid samples with stainless-steel than in those with copper strips. In the experiments incubating the host bacteria samples directly on Petri dishes and in liquid samples, copper metal outperformed stainless-steel under both conditions Although the effect of this metal in both liquid and agar is promising, further studies are needed to address the application of these results to strategies for reducing the effects of viruses and bacteria on human health in clinical practice.

\section{Conclusions}

This study investigated the effects of metal plates on contact killing of bacteria and viruses and the influences of electricity and physical barriers on those effects. Electricity increased the reduction in bacterial growth, but this effect was reduced by a physical barrier. Metals also reduced the growth of viruses in liquid samples.

Author Contributions: The research methodology was done mainly by M.V., W.J. and M.L.B. M.K. also contributed statistical knowledge and S.K. had supported the funding of this study. All writing the original draft as well as other revisions were done by M.V. Moreover, conceptualization and supervision was done by D.P.

Funding: This work was supported by the grant from the R\&D Program of the Korea Railroad Research Institute (KRRI), Republic of Korea.

Acknowledgments: The authors would like to acknowledge the administrative teams of KRRI and also the other members of our own team, Transportation Environmental Research Team.

Conflicts of Interest: The authors declare no conflict of interest. 


\section{References}

1. Warnes, S.L.; Green, S.M.; Michels, H.T.; Keevil, C.W. Biocidal efficacy of copper alloys against pathogenic enterococci involves degradation of genomic and plasmid DNA. Appl. Environ. Microbiol. 2010, 76, 5390-5401. [CrossRef] [PubMed]

2. Espirito Santo, C.; Lam, E.W.; Elowsky, C.G.; Quaranta, D.; Domaille, D.W.; Chang, C.; Grass, G. Bacterial killing by dry metallic copper surfaces. Applied Environ. Microbiol. 2011, 77, 794-802. [CrossRef] [PubMed]

3. Grass, G.; Rensing, C.; Solioz, M. Metallic copper as an antimicrobial surface. Appl. Environ Microbiol. 2011, 77, 1541-1547. [CrossRef] [PubMed]

4. Dollwet, H.H.A.; Sorenson, J.R.J. Historic uses of copper compounds in medicine. Trace Elem. Med. 1985, 2, 80-87.

5. Sudha, V.B.P.; Singh, O.; Prasad, S.R.; Venkatasubramanian, P. Killing of enteric bacteria in drinking water by a copper device for use in the home: Laboratory evidence. Trans. R. Soc. Trop. Med. Hygiene 2009, 103, 819-822. [CrossRef]

6. Kuhn, P.J. Doorknobs: A Source of Nosocomial Infection? Copper Development Association: New York, NY, USA, 1983. Available online: http://www.copperinfo.co.uk/antimicrobial/downloads/kuhn-doorknob.pdf (accessed on 4 September 2019).

7. Marais, F.; Mehtar, S.; Chalkley, L. Antimicrobial efficacy of copper touch surfaces in reducing environmental bioburden in a South African community healthcare facility. J. Hosp. Infect. 2010, 74, 80-82. [CrossRef]

8. Depner, R.F.P.; Pontin, K.P.; Depner, R.A.; Flores Neto, A.; Lucca, V.; Lovato, M. Action of antimicrobial copper on bacteria and fungi isolated from commercial poultry hatcheries. Braz. J. Poult. Sci. 2016, 18, 95-97. [CrossRef]

9. Kusumaningrum, H.D.; Riboldi, G.; Hazeleger, W.C.; Beumer, R.R. Survival of foodborne pathogens on stainless steel surfaces and cross-contamination to foods. Int. J. Food Microbiol. 2003, 85, 227-236. [CrossRef]

10. Cha, J.S.; Cooksey, D.A. Copper resistance in Pseudomonas syringae meditated by periplasmic and outer membrane proteins. Proc. Natl. Acad. Sci. USA 1991, 88, 8916-8919. [CrossRef]

11. Macomber, L.; Imlay, J. The iron-sulfur clusters of dehydrates are primary intracellular targets of copper toxicity. Proc. Natl. Acad. Sci. USA 2009, 106, 8344-8349. [CrossRef]

12. Van der Borden, A.J.; Vn der Mei, H.C.; Busscher, H.C. Electric block current induced detachment from surgical stainless steel and decreased viability of Staphylococcus epidermidis. Biomarerials 2005, 26, 6731-6735. [CrossRef] [PubMed]

13. Del Pozo, J.L.; Rouse, M.S.; Euba, G.; Kang, C.I.; Mandrekar, J.N.; Steckelberg, J.M.; Patel, R. The electricidal effect is active in an experimental model of Staphylococcus epidermidis chronic foreign body osteomyelitis. Antimicrob. Agents Chomother. 2009, 53, 4064-4068. [CrossRef] [PubMed]

14. Del Pozo, J.L.; Rouse, M.S.; Mandrekar, J.N.; Steckelberg, J.M.; Patel, R. The electrical effect: Reduction of Staphylococcus and Pseudomonas biofilms by prolonged exposure to low-intensity electrical current. Antimicrob. Agents Chemother. 2009, 53, 41-45. [CrossRef] [PubMed]

15. Hulsheger, H.; POtel, J.; Nieman, E.G. Electric field effects on bacteria and yeast cells. Radiat. Environ. Biophys. 1983, 22, 149-162. [CrossRef]

16. Pareilleux, A.; Sicard, N. Lethal effects of electric current on Escherichia coli. Appl. Microbiol. 2007, 19, 421-424.

17. Ruiz-Ruigomez, M.; Badiola, J.; Schimdt-Malan, S.M.; Greenwood-Quaintance, K.; Karau, M.J.; Brinkman, C.L.; Mandrekar, J.N.; Patel, R. Direct electrical current reduces bacterial and yeast biofilm formation. Int. J. Bacteriol. Hindawi Pub. Corp. 2016, 2016, 6. [CrossRef]

18. Zituni, D.; Schutt-Gerowitt, H.; Kopp, M.; Addicks, K.; Hoffman, C.; Hellmich, M.; Faber, F.; Niedermeier, W. The growth of Staphylococcus aureus and Escherichia coli in low-direct current electric fields. Int. J. Oral Sci. 2014, 6, 7-14. [CrossRef]

19. Zvitov, R.; Zohor-Perez, C.; Nussinovitch, A. Short-duration low-direct current electrical field treatment is a practical tool for considerably reducing counts of gram-negative bacteria entrapped in gel beads. Appl. Environ. Microbiol. 2004, 70, 3781-3784. [CrossRef]

20. Versoza, M.; Jung, W.; Barabad, M.L.; Lee, Y.; Choi, K.; Park, D. Inactivation of filter bound aerosolized MS2 bacteriophages using a non-conductive ultrasound transducer. J. Virol. Methods 2018, 255, 76-81. [CrossRef]

21. Halliwell, B.; Gutteridge, J.M.C. Free Radicals in Biology and Medicine, 2nd ed.; Clarendon Press: Oxford, UK, 1989. 
22. Lloyd, D.R.; Phillips, D.H. Oxidative DNA damage mediated by copper (II), iron (II), and nickel (II) Fenton reactions: Evidence for site-specific mechanisms in the formation of double-strand breaks, 8-hydroxydeoxyguanosine and putative intrastrand cross-links. Mutat. Res. 1999, 424, 2-36. [CrossRef]

23. Solioz, M.; Abieht, H.K.; Mermod, M. Response of Gram-positive bacteria to copper stress. J. Biol. Inorg. Chem. 2010, 15, 3-14. [CrossRef] [PubMed]

24. Thieme, D.; Grass, G. The Dps protein of Escherichia coli is involved in copper homeostasis. Microbiol. Res. 2010, 165, 109-115. [CrossRef] [PubMed]

25. Imlay, J.A. Pathways of oxidative damage. Annu. Rev. Microbiol. 2003, 57, 395-418. [CrossRef] [PubMed]

26. Keyer, K.; Imlay, J.A. Superoxide accelerates DNA damages by evaluating free-iron levels. Proc. Natl. Acad. Sci. USA 1996, 93, 13635-13640. [CrossRef] [PubMed]

27. Shtatland, T.; Gill, S.C.; Javornik, B.E.; Johansson, H.E.; Singer, B.S.; Uhlenbeck, O.C.; Zichi, D.A.; Gold, L. Interactions of Escherichia coli RNA with bacteriophage MS2 coat protein: genomic SELEX. Nucleic Acids Res. 2000, 28, e93. [CrossRef] [PubMed]

28. Chamakura, K.R.; Tran, J.S.; Young, R. MS2 lysis of Escherichia coli depends on host chaperone DNA. J. Bacteriol. ASM 2017, 199, e00058-17.

29. Noyce, J.O.; Michels, H.; Keevil, C.W. Inactivation of influenza A virus on copper versus stainless steel surfaces. Appl. Environ. Microbiol. 2007, 73, 2748-2750. [CrossRef]

30. Abad, F.X.; Pinto, R.M.; Diez, J.M.; Bosch, A. Disinfection of human enteric viruses in water by copper and silver in combination with low levels of chlorine. Appl. Environ. Microbiol. 1994, 60, 2377-2383.

31. Armstrong, A.M.; Sobsey, M.D.; Casanova, L.M. Disinfection of bacteriophage MS2 by copper in water. Appl. Microbiol Biotechnol. 2017, 101, 6891-6897. [CrossRef]

(C) 2019 by the authors. Licensee MDPI, Basel, Switzerland. This article is an open access article distributed under the terms and conditions of the Creative Commons Attribution (CC BY) license (http://creativecommons.org/licenses/by/4.0/). 